\title{
Potential of Casein as a Carrier for Biologically Active Agents
}

\author{
Tomasz Konrad Głąb ${ }^{1} \cdot J^{\prime}$ anusz Boratyński ${ }^{1,2}$
}

Received: 6 April 2017/ Accepted: 29 June 2017/Published online: 15 July 2017

(C) The Author(s) 2017. This article is an open access publication

\begin{abstract}
Casein is the collective name for a family of milk proteins. In bovine milk, casein comprises four peptides: $\alpha_{\mathrm{S} 1}, \alpha_{\mathrm{S} 2}, \beta$, and $\kappa$, differing in their amino acid, phosphorus and carbohydrate content but similar in their amphiphilic character. Hydrophilic and hydrophobic regions of casein show block distribution in the protein chain. Casein peptides carry negative charge on their surface as a result of phosphorylation and tend to bind nanoclusters of amorphous calcium phosphate. Due to these properties, in suitable conditions, casein molecules agglomerate into spherical micelles. The high content of casein in milk $(2.75 \%)$ has made it one of the most popular proteins. Novel research techniques have improved understanding of its properties, opening up new applications. However, casein is not just a dietary protein. Its properties promise new and unexpected applications in science and the pharmaceutical and functional food industries. One example is an encapsulation of health-related substances in casein matrices. This review discusses gelation, coacervation, self-assembly and reassembly of casein peptides as means of encapsulation. We highlight information on encapsulation of health-related substances such as drugs and dietary supplements inside casein micro- and nanoparticles.
\end{abstract}

Keywords Casein · Milk proteins · Encapsulation · Release $\cdot$ Delivery $\cdot$ Carriers

Tomasz Konrad Głąb

tomasz.glab@ajd.czest.pl

$\triangle$ Janusz Boratyński

borat@iitd.pan.wroc.pl

1 Department of Biomedical Sciences, Faculty of Mathematics and Natural Sciences, Jan Dlugosz University in Czestochowa, 13/15 Armii Krajowej Avenue, 42-200 Czestochowa, Poland

2 Laboratory of Biomedical Chemistry "NeoLek", Hirszfeld Institute of Immunology and Experimental Therapy, Polish Academy of Sciences, 12 Rudolf Weigl Street, 53-114 Wroclaw, Poland 


\section{Introduction}

Casein (derived from the Latin caseus for 'cheese') [1] is the collective term for a family of secreted calcium (phosphate) binding phosphoproteins found in mammalian milk [2]. Caseins, in contrast to the second milk protein fraction, i.e. whey proteins, are insoluble and account for $80 \%$ of total bovine milk proteins [3, 4], which translates to $2.75 \%$ of total milk components (Fig. 1).

Eutherian milk contains products of at least three and at most five genes that encode casein peptides. Bovine milk contains products of four genes: $\alpha_{\mathrm{S}^{-}}, \alpha_{\mathrm{S}^{-}}, \beta-$ and $\kappa$-casein, in assumed weight ratio of 4:1:4:1 [2, 5]. However, milk from various breeds of cow contains caseins in various proportions [6]. All casein peptides are amphiphilic (Fig. 2), but they differ in their amino acid, phosphorus and carbohydrate content (Table 1) [5, 7]. Only $\kappa$-casein, containing two cysteines, can form disulphide bonds $[8,9]$. Secondary structures such as $\alpha$-helices and $\beta$ -

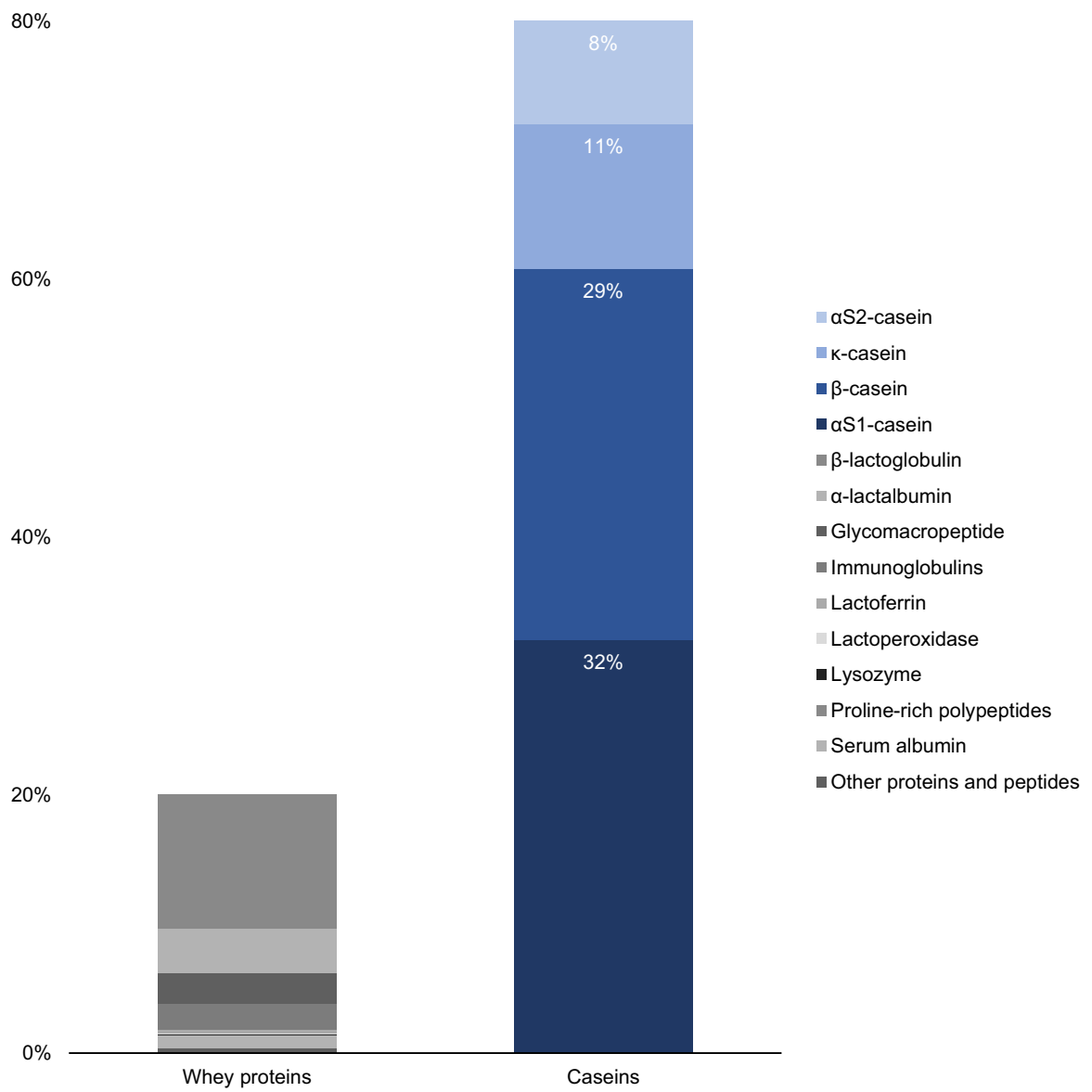

Fig. 1 Standard protein content in bovine milk. Although whey proteins show greater diversity, caseins are more abundant. (Adapted and modified from Artym and Zimecki [3]) 

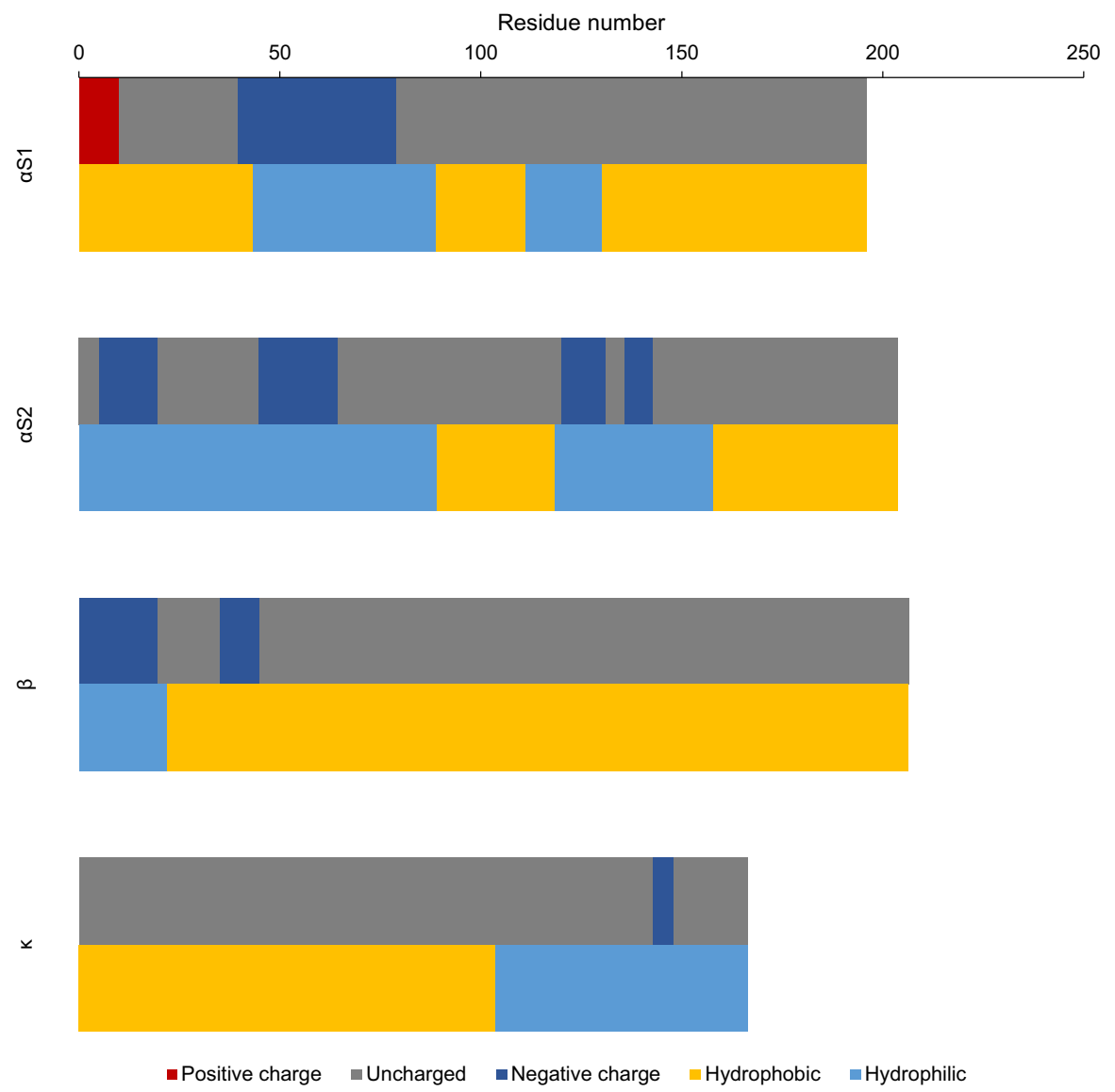

Fig. 2 Schematic diagram of linear chain distribution of charged, hydrophilic and hydrophobic regions for the most common genetic types of caseins at the $\mathrm{pH}$ of milk (6.6). (Adapted and modified from Swaisgood and Kessler et al. [12, 13])

Table 1 Differences in selected molecular properties of caseins

\begin{tabular}{lllll}
\hline Fraction & $\begin{array}{l}\text { Molecular } \\
\text { weight }(\mathrm{kDa})\end{array}$ & $\begin{array}{l}\text { Length of } \\
\text { chain (aa) }\end{array}$ & $\begin{array}{l}\text { Number of cysteine } \\
\text { residues in chain }\end{array}$ & $\begin{array}{l}\text { Number of phosphoserine } \\
\text { residues in chain }\end{array}$ \\
\hline$\alpha_{\mathrm{S} 1}$ & 24.5 & 214 & 1 & 9 \\
$\alpha_{\mathrm{S} 2}$ & 26.0 & 222 & 3 & 10 \\
$\beta$ & 25.1 & 224 & 1 & $4-5$ \\
$\kappa$ & 21.3 & 190 & 2 & 2 \\
\hline
\end{tabular}

Data taken from UniProtKB database [16-19]

sheets are not frequent, thus making caseins flexible, unfolded or random-coil peptides capable of creating intermolecular, e.g. electrostatic, hydrogen and hydrophobic, interactions $[2,10]$. Therefore, in solution, caseins are present in a number of conformations that are most energy favourable [9]. Such conformations 
explain the low sensitivity of caseins to denaturation during, e.g. thermal treatment of milk [11].

Caseins display activity similar to the small heat-shock proteins, in this case one casein molecule acting as a molecular chaperone towards the other casein molecule or other protein (e.g. whey protein), stabilising the target and preventing its unfavourable aggregation [2]. Therefore, under suitable conditions, casein peptides are present in the form of an amorphous, stable agglomerate known as a casein micelle (from the Latin mica for 'crumb' or 'morsel') [11] with radius of $50-500 \mathrm{~nm}$ and mass of $10^{3}-3 \times 10^{6} \mathrm{kDa}$ [9]. However, this broad distribution occurs in pooled milk, whereas the size of micelles is constant for a particular cow during milking, lactation and over a period of years [14]. The internal structure of the micelle is porous $[15,16]$. Images obtained by cryo-transmission electron microscopy (cryo-TEM) show irregular channels, more than $5 \mathrm{~nm}$ in diameter, and inner cavities with diameter of 20-30 nm [15].

Caseins have capacity for binding phosphorus and calcium and proline- and glutamine-rich sequences, which are responsible for their intermolecular affinity $[2,4]$. A typical casein micelle contains thousands of casein molecules, forming $94 \%$ of the micelle. Most of them form thermodynamically stable complexes with amorphous calcium phosphate, which accounts for $6 \%$ of the micelle [2, 5]. Amorphous calcium phosphate forms spherical nanoclusters with diameter of $3.5-5.0 \mathrm{~nm}$, spaced $\sim 18 \mathrm{~nm}$ apart [21]. Phosphate is bound to the protein by phosphoseryl residues [22]. An enzyme responsible for phosphorylation of caseins is Golgi kinase, known as Fam20C and not to be confused with casein kinase 1 and 2 , named after a model substrate used for their identification [23].

In the structure of a casein micelle, peptides $\alpha_{\mathrm{S} 1}, \alpha_{\mathrm{S} 2}$, and $\beta$ build up mostly in the inner part, while $\kappa$-casein forms the outer 'hairy' layer that stabilises the micelle sterically [5]. This stabilisation is possible because $\kappa$-casein has a glycosylated hydrophilic part that protrudes into the aqueous surrounding, known as glycomacropeptide [24, 25]. Interestingly, this 'hairy' layer is unevenly distributed and only partially covers the micellar surface [26] (Fig. 3).

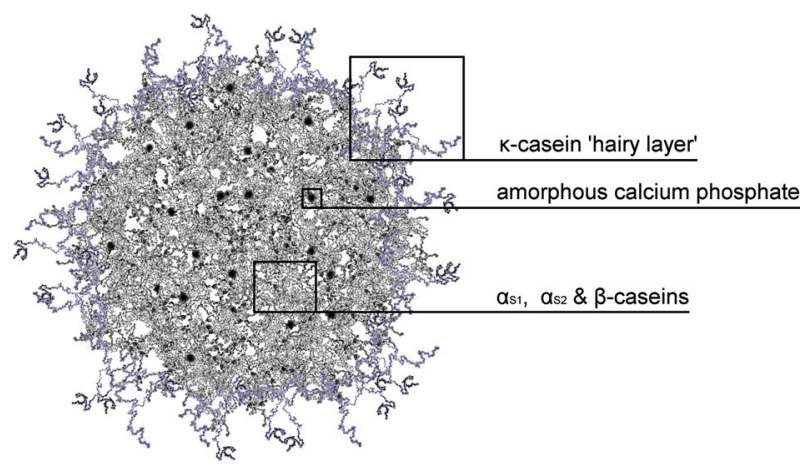

Fig. 3 Original graphical representation of casein micelle cross-section according to the model proposed by Holt [27]. Artistic impression of casein micelle particle 
The actual internal structure of a casein micelle remains uncertain, and various models have been constructed to describe it $[14,16]$. Since casein is secreted by mammary epithelial cells [28], the distinctive structure of the micelles is an effect of evolution and plays an important biological role: calcium phosphate is sequestered in the core to avoid precipitation, and casein molecules aggregate around it to prevent formation of amyloid fibrils in mammary tissue [2], allowing mothers to feed neonates without ill consequences.

Casein micelles exhibit $\mathrm{pH}$-dependent behaviour, tightening as the $\mathrm{pH}$ drops and swelling with increase of $\mathrm{pH}[29,30]$. The zeta potential measured for casein micelles was found to be $-8 \mathrm{mV}$ at neutral $\mathrm{pH}$ and close to $0 \mathrm{mV}$ on decreasing the $\mathrm{pH}$. Upon reaching the point where the micelles become unstable, it becomes hard to estimate the potential, but it is expected to be 0 at around $\mathrm{pH} 4.8$ and have positive values at lower $\mathrm{pH}$ [31]. Thus, swelling of the micelles can be explained by a $\mathrm{pH}$-driven increase of negative charge that results in stronger electrostatic repulsion between casein molecules, leading to loosening of the micellar structure and increase in size [30], while tightening can be explained by a decrease of charge with decreasing $\mathrm{pH}$.

Lowering the $\mathrm{pH}$ below the isoelectric point of 4.6-4.8 causes aggregation and precipitation of micelles combined with release of calcium [5, 32, 33], indicating the great importance of cation availability for formation of casein micelles. In fact, studies on sodium and calcium caseinates [34, 35] as well as casein [36] show that different cations can influence the micelle structure in a complex manner.

Casein has many advantages including low price and simple production. Industrial manufacture of casein involves a coagulation process that can be carried out by two means: enzymatic or acid gelation/precipitation (Fig. 4) as in cheesemaking [10, 37]. Only acid casein can be easily resolubilised, which is achieved by converting it to salt, caseinate, using alkalis [10, 34].

Due to its simple processing, in addition to its obvious utilisation in the food industry, casein is also applied in other fields, including glues, plastics and textile fibres [10]. Additionally, due to its dietary role, casein is generally recognised as safe (GRAS), and offers biocompatibility, biodegradability and bioresorbability in oral administration. Those characteristics make casein a promising candidate for encapsulation matrix. The aim of this review is to present recent advances in encapsulation utilising casein.

\section{Casein Delivery Particles}

As the $\mathrm{pH}$ is highly acidic in the human stomach but neutral in the duodenum [38], the $\mathrm{pH}$-dependent behaviour of casein micelles can be beneficial for controlled release of substances administered orally. Additionally, caseins can penetrate the plasma membrane in an energy-independent fashion [39], which can enhance cellular uptake on oral administration. Furthermore, the unfolded structure of caseins makes them easily accessible for proteolysis [9], ensuring good release by proteolytic enzymes in the gastrointestinal tract. The amphiphilic nature of caseins allow micelles to exhibit natural affinity for hydrophobic substances [40] as well as 
(a)
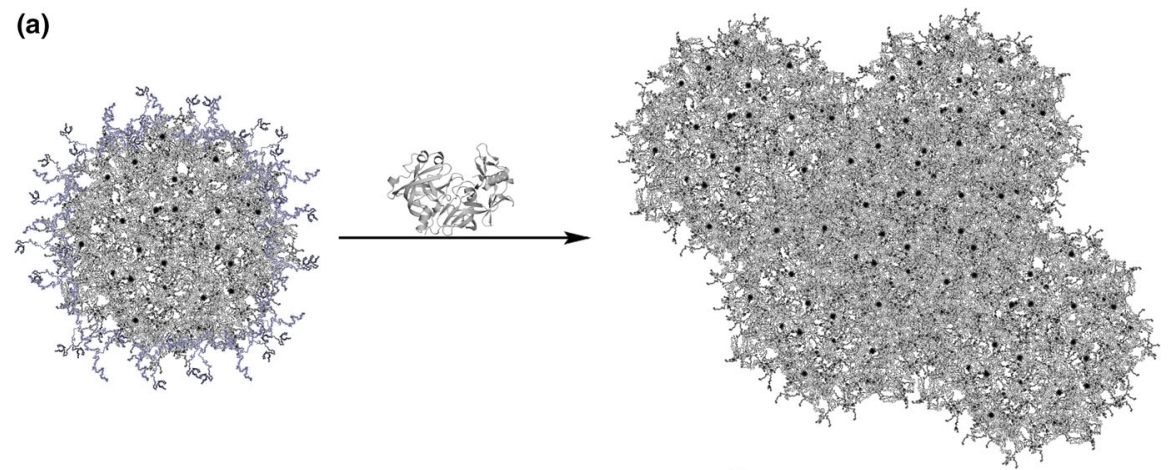

(b)

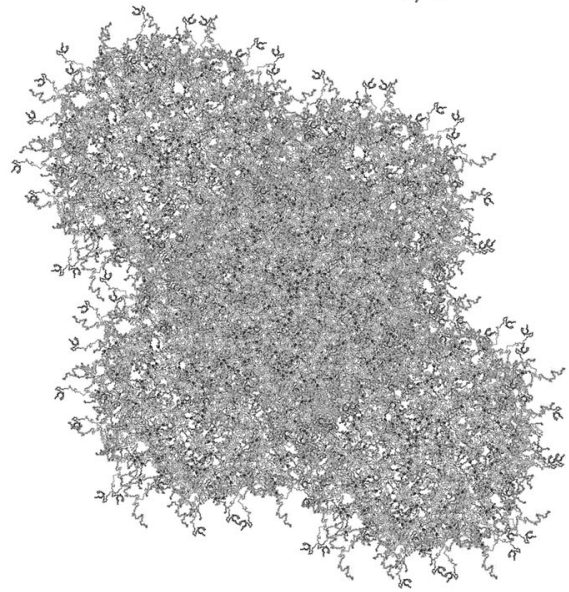

Fig. 4 Methods commonly used for casein gelation. a Enzymatic method utilising chymosin, an enzyme found in rennet, for cleavage of hydrophilic $\kappa$-casein, leading to destabilisation of micelles and coagulation. b Lowering the $\mathrm{pH}$ to $\mathrm{pI}(4.6)$ using mineral $(\mathrm{HCl})$ or organic (i.e. bacterial lactic) acid leads to neutralisation of surface charge and subsequent gelation

hydrophilic macromolecules such as whey proteins and polysaccharides [41]. All of these features make casein a promising candidate for encapsulation matrix.

Casein delivery particles can be categorised based on their type and size. According to the International Union of Pure and Applied Chemistry (IUPAC) definition, particles can be divided into capsules with a solid shell and core space available to entrap substances, and spherical particles without a membrane or outer layer. In terms of size, particles with dimensions of $0.1-100 \mu \mathrm{m}$ are granted the prefix 'micro', whereas particles in the range of $1-100 \mathrm{~nm}$ are prefixed 'nano'. However, the size limit between 'micro' and 'nano' remains controversial [42].

Casein has been used as an encapsulation material for all the above-mentioned types of particles. Different substances have been encapsulated, possessing pharmaceutical, health-related and nutritional value. Even though approaches for encapsulation of nutraceuticals and nutrients may differ from methods used to encapsulate pharmaceuticals, the former are still interesting and may find 
pharmaceutical applications as well. In fact, many preparations initially tested for encapsulation of nutraceuticals were eventually tested for drugs.

\subsection{Microparticles}

The first papers on use of casein for microencapsulation were published in the late 1980s [43, 44], and since then much work has been carried out. This review highlights the most recent research.

Casein exhibits outstanding gelation properties, which have been utilised together with emulsification for encapsulation of probiotic bacteria such as Bifidobacterium lactis, Lactobacillus casei, Lactobacillus paracasei and Lactobacillus rhamnosus [45-48].

One of the methods used to achieve this is cross-linking the protein with transglutaminase (Fig. 5). Such cross-linking results in gelation of the casein and thus entrapment of bacterial cells [46, 47]. However, after freeze-drying and 3 months of storage in optimised conditions $\left(4^{\circ} \mathrm{C}\right.$ and relative humidity of $11 \%$ ), significant loss of living cells was observed. This phenomenon is thought to be unavoidable, hence authors have proposed addition of protective substances [47].

Casein and whey proteins are other materials used for encapsulation of probiotic bacteria [45]. Micellar casein and/or whey proteins were mixed with probiotic cells, and rennet was added to induce gelation. Subsequently, the product was subjected to gastric digestion in simulated gastric fluid and monitored in situ using a particle size and shape analyser. A formulation consisting of denatured whey proteins and micellar casein gave the best results in terms of distribution breadth, elastic

(a)

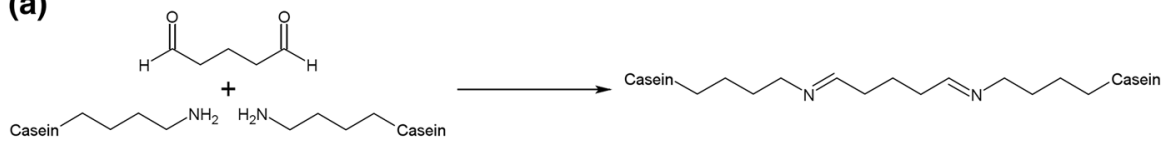

(b)

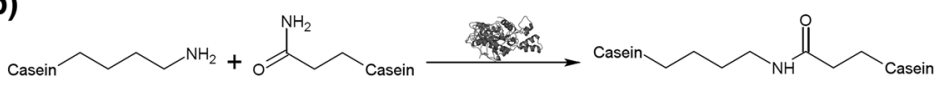

(c)
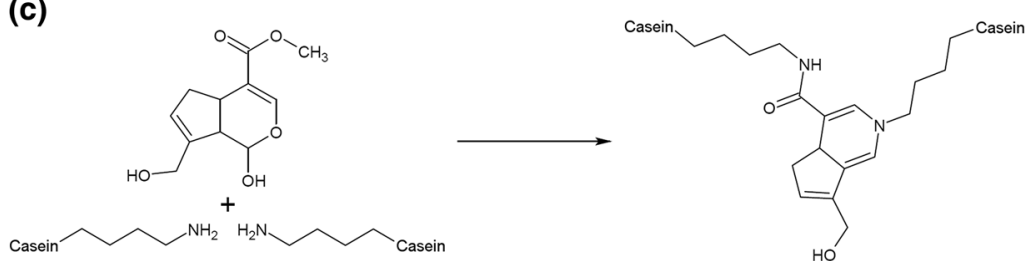

Fig. 5 Schematic reactions for different agents used for cross-linking of casein. a Reaction of glutaraldehyde with $\varepsilon$-amine groups of protein yields a non-conjugated Schiff base as a result of nucleophilic attack on the aldehyde groups. Additionally, in alkaline solution, polymeric glutaraldehyde can form and react with proteins [49]. b Enzymatic acyl-transfer reaction between $\gamma$-carboxamide group of glutamine residue and $\varepsilon$-amino group of lysine residue facilitated by transglutaminase results in $\varepsilon$ - $(\gamma-$ glutamyl)lysine isopeptide bonds [50]. c Genipin cross-linking results from nucleophilic attack on genipin ring by primary amine group followed by nucleophilic substitution of ester group [51] 
modulus, encapsulation rate, half-time of gastric digestion, particle size and survival rate.

Even though casein microparticles can resist low $\mathrm{pH}$, they are readily digested by pepsin in vitro and offer insufficient protection to probiotic bacteria in vivo. To prevent this phenomenon, a fat coating was introduced, granting these particles resistance to pepsin digestion in vitro. However, when tested on mice, the particles were still easily digested, presumably through the action of gastric lipases [48]. Nonetheless, it is possible that other coating materials could be suitable for this task.

Recently, spray-drying instead of emulsification was also used for microencapsulation of probiotic bacteria [52]. Micellar casein was mixed with denatured whey proteins and chymosin. After enzymatic cleavage of $\kappa$-casein, L. rhamnosus lyophilisate was added and the mixture was spray-dried. The survival rate of bacterial cells after spray-drying was satisfactory, but the preparation was not tested in model gastric conditions. Nonetheless, the obtained microparticles exhibited interesting behaviour during reconstitution in water: at $8{ }^{\circ} \mathrm{C}$, probiotic cells were released, while at $40{ }^{\circ} \mathrm{C}$, gel formation caused entrapment. This finding offers perspectives for storage of probiotic cells.

Caseins were found to interact with polysaccharides, forming coacervate-type complexes [53-56]. Coacervation is triggered by adjusting the $\mathrm{pH}$ below the isoelectric point of casein. Such low $\mathrm{pH}$ is necessary as both casein and polysaccharides have negative charge in neutral $\mathrm{pH}$, repelling each other. Shifting the $\mathrm{pH}$ to low values results in positive charge on the proteins, allowing them to interact with the negatively charged polysaccharide chains [55].

The coacervation method was reported to be suitable for encapsulation of volatile compounds $[55,56]$. After mixing sodium caseinate or whey protein isolate with carboxymethyl cellulose, $\beta$-pinene was added and oil-in-water emulsions were prepared. Coacervation was conducted at $\mathrm{pH}$ 2.8. Higher protein-to-polysaccharide ratio was more beneficial through the formation of a network in which $\beta$-pinene could be entrapped, being more evident in the case of whey proteins, supposedly due to partial unfolding at low $\mathrm{pH}$ [55]. Addition of reticulating agents, crosslinking via hydrogen bonds, during coacervation gave contradictory results: tannic acid did not induce any significant change, whilst glycerol gave a 1.5- to 2-fold increase in encapsulation efficiency in the case of caseinate and above 2.2-fold in the case of whey protein isolate. The authors attributed these differences to the size of the compounds utilised, as the small glycerol molecules were able to fill the pores in the microcapsules sealing them, while tannic acid could cause disruption of the matrix during coacervation [56].

Jain et al. used gum tragacanth for coacervation with casein to encapsulate $\beta$ carotene [53] and lycopene [54]. Briefly, the bioactive compounds were dissolved in rice bran oil and emulsified with casein. Gum tragacanth was added to obtained oilin-water emulsions, and the $\mathrm{pH}$ was adjusted from 10.5 to 2.0 to trigger coacervation. Complexes were then treated with genipin to cross-link the coating material. Despite the initial burst release attributed to adsorbed or externally encapsulated $\beta$-carotene, microcapsules generally exhibited a good release curve during in vitro release studies. Additionally, microcapsules retained good stability during 2 months of storage, especially at $4{ }^{\circ} \mathrm{C}$ [53]. The stability and residual action 
of lycopene-loaded capsules were shown to be significantly enhanced in comparison with lycopene in oil. Furthermore, twofold better bioavailability was observed in rats for microencapsulated lycopene [54].

In other work, casein was coacervated with pectin. Indomethacin was mixed with casein/pectin solution, and coacervation was triggered by slowly reducing the $\mathrm{pH}$ to 3.5 [57]. The same procedure was followed for acetaminophen (paracetamol). Some formulations used in this study were additionally cross-linked with glutaraldehyde. The obtained microparticles were able to prolong indomethacin release, and the interaction between casein and pectin did not prevent the enzymatic breakdown of pectin. However, cross-linking inhibited enzymatic digestion of pectin without prolonging release. The formulation was shown to be unsuitable for water-soluble drugs such as acetaminophen, which exhibited rapid release.

Casein was shown to act as an antioxidant in emulsions and microspheres [58]. Microspheres were prepared from sodium caseinate and pectin, emulsified with fish oil, followed by cross-linking with transglutaminase. The stability of microencapsulated fish oil was then compared with that of emulsions prepared with fish oil and casein or Tween 20. Specimens stabilised with caseinate oxidised slower than those stabilised with Tween 20, and interestingly no significant differences were shown between caseinate emulsions and caseinate microspheres.

Flaxseed oil and quillaja saponin were emulsified and mixed with sodium alginate and sodium caseinate. Then, using an encapsulation unit, droplets were injected into calcium chloride solution to facilitate gelation. Sodium caseinate was shown to effectively inhibit lipid oxidation during 50 days of storage at $55{ }^{\circ} \mathrm{C}$ [59].

Flaxseed oil was also microencapsulated in caseinate and whey protein concentrate-based microcapsules prepared by emulsification followed by spraydrying. After 6 months of storage at $35^{\circ} \mathrm{C}$, the microcapsules showed high oxidative stability. When tested in simulated gastric fluid and simulated intestinal fluid conditions, the caseinate microcapsules showed nearly twofold higher release than whey protein concentrate capsules [60].

\subsection{Nanoparticles}

Many biofluids, including milk, contain phosphate and calcium in concentrations exceeding the limits of solubility that are stabilised by proteins [21]. Caseins fulfill this role through their natural ability to self-assemble into micelles in presence of calcium phosphate [61]. In some way, this phenomenon can be perceived as encapsulation invented by Nature itself. The concentration of casein monomers at which micelles appear, i.e. the critical micelle concentration (CMC), is considered to be $1.0 \mathrm{mg} / \mathrm{ml}$ [29], but various factors affect casein micellisation in different ways. Furthermore, hydrophobic regions of caseins can interact with other hydrophobic substances. These characteristics can be harnessed to create delivery nanoparticles.

The first report treating casein micelles as nanocapsules was published by Semo et al. Those authors were able to incorporate fat-soluble vitamin $\mathrm{D}_{2}$ in hydrophobic regions of reconstituted casein micelles [40]. Moreover, two different papers concerning binding of lipophilic compounds to hydrophobic regions of caseins were 
published at roughly the same time, but the authors did not consider the obtained products to be capsules [62, 63]. This led to a series of other studies concerning encapsulation of hydrophobic compounds in reassembled casein micelles using different approaches (Table 2). The process of creating loaded reassembled casein micelles consists of three phases. The first step is disruption of the micellar structure, which is achieved by, inter alia, high-pressure treatment, ultrasound treatment or simply using caseinate already deprived of its micellar structure [40, 64, 65]. Then, lipophilic substances dissolved in organic solvents such as ethanol are added. Ethanol has a dissociative effect on casein, presumably due to increased solubility of caseins by reduction of phosphoseryl cross-linking and increased protein hydrophobicity [66]. In the next step, removal of disrupting agent and organic solvent allows hydrophobic substances to bind to lipophilic regions of

Table 2 Techniques utilised for preparing loaded reassembled casein micelles

\begin{tabular}{|c|c|c|c|}
\hline Category & Substance & Technique & References \\
\hline \multirow[t]{6}{*}{ Pharmaceuticals } & Triclosan & High pressure homogenisation & {$[63]$} \\
\hline & Flutamide & Spray-drying & {$[65]$} \\
\hline & & & {$[66]$} \\
\hline & Curcumin & Spray-drying & {$[67]$} \\
\hline & & $\mathrm{pH}$-shifting & {$[68]$} \\
\hline & & High pressure treatment & {$[69]$} \\
\hline \multirow[t]{14}{*}{ Nutraceuticals } & Vitamin $\mathrm{D}_{2}$ & $\begin{array}{l}\text { Restoration of mineral composition and ultra- } \\
\text { high pressure homogenisation }\end{array}$ & [59] \\
\hline & & High pressure treatment & {$[70]$} \\
\hline & & & [71] \\
\hline & Vitamin $\mathrm{D}_{3}$ & $\begin{array}{l}\text { Restoration of mineral composition and ultra- } \\
\text { high pressure homogenisation }\end{array}$ & $\begin{array}{l}{[72]} \\
{[73]}\end{array}$ \\
\hline & & & [74] \\
\hline & $\beta$-carotene & Solvent displacement & {$[60]$} \\
\hline & & Emulsification-evaporation & {$[61]$} \\
\hline & & $\begin{array}{l}\text { Restoration of mineral composition and ultra- } \\
\text { high pressure homogenisation }\end{array}$ & [75] \\
\hline & & $\begin{array}{l}\text { Restoration of mineral composition and spray- } \\
\text { drying }\end{array}$ & [76] \\
\hline & & High pressure homogenisation & [77] \\
\hline & & Restoration of mineral composition & [78] \\
\hline & Vitamin $\mathrm{B}_{9}$ & Coacervation and spray-drying & [79] \\
\hline & $\begin{array}{l}\omega-3 \text { polyunsaturated } \\
\text { fatty acids }\end{array}$ & $\begin{array}{l}\text { Restoration of mineral composition and ultra- } \\
\text { high pressure homogenisation }\end{array}$ & {$[80]$} \\
\hline & Fucoxanthin & $\begin{array}{l}\text { Restoration of mineral composition and spray- } \\
\text { drying }\end{array}$ & [81] \\
\hline \multirow[t]{3}{*}{ Nutrients } & Soybean oil & $\mathrm{pH}$ changes and ultrasound treatment & {$[62]$} \\
\hline & Rapeseed oil & & \\
\hline & Fish oil & & \\
\hline
\end{tabular}


caseins and the micelles to reassemble (Fig. 6). In the case of caseinate, an extra step is necessary to recreate the micellar structure: restoration of the mineral composition achieved by addition of certain salts [40].

Recently, reassembled casein nanocapsules loaded with vitamin $\mathrm{D}_{3}$ were shown to provide bioavailability of vitamin D comparable to that in Tween 80 [74, 75] and successfully underwent clinical trials, showing bioavailability similar to that in fat [76]. Furthermore, different casein nanoparticles were shown to protect the content against cold storage, heat, high hydrostatic pressure processing, oxidation and ultraviolet (UV) radiation [40, 74, 77, 80, 82]. Nonetheless, reassembled casein nanoparticles are readily digested by gastrointestinal proteases [79-81]. This could be beneficial for stomach delivery, but when the intestine is targeted, additional factors should be introduced to reduce gastric digestion.

Interaction of caseins with other polymers was another process used for preparation of nanoparticles. Casein-pectin polyelectrolyte complexes were fabricated by slow acidification with glucono- $\delta$-lactone and heating. Rutin was chosen as a model encapsulated compound. The obtained nanoparticles showed delayed proteolysis in simulated gastric conditions and sustained release in simulated intestinal conditions [84]. A casein-zein complex was used to co-encapsulate eugenol and thymol before spray-drying. After rehydration, the capsules were stable and allowed the content to exhibit bacteriostatic effects against Escherichia coli and Listeria monocytogenes [85]. Kessler et al. mixed casein rich in $\alpha_{S^{-}}$-casein with triblock copolymer $\mathrm{PEO}_{13}-\mathrm{PPO}_{30}-\mathrm{PEO}_{13}$ [13]. Micelles containing both polymers were formed and could solubilise pyrene.

Self-assembled nanoparticles were also prepared with chemically modified protein. Casein grafted with dextran was prepared by means of Maillard reaction [86]. $\beta$-Carotene was incorporated into spherical nanocapsules composed of a $\beta$ carotene core surrounded by casein molecules with dextran chains facing outside. The obtained nanocapsules were water soluble, stable, and upon digestion with proteases could release their content. Aqueous dispersion of nanoparticles was stable against oxidation, $\mathrm{pH}$ change and ionic strength change [86]. In other work, the Amadori rearrangement of the Maillard reaction was used to prepare caseingraft-dextran copolymer [87]. The product exhibited $\mathrm{pH}$-dependent behaviour with micellisation occurring at $\mathrm{pH}$ equal to the $\mathrm{pI}$ of casein and successfully encapsulated pyrene as a model substance, used as a fluorescence marker. The Maillard reaction was also used to conjugate casein and maltodextrin [88]. Nanocapsules were able to

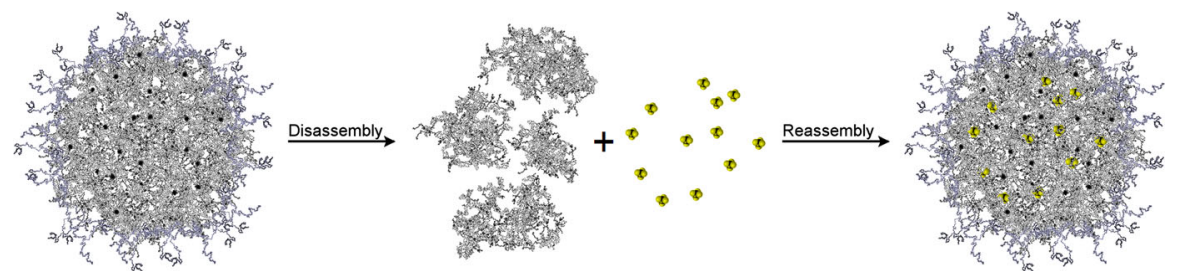

Fig. 6 Graphical representation of general principle behind reassembled casein nanospheres. Briefly, the micellar structure is disrupted, lipophilic compounds dissolved in organic solvents bind to hydrophobic regions of casein peptides, then caseins are reassembled, creating new, substance-loaded nanoparticles 
protect vitamin $\mathrm{D}_{2}$ in gastric-like conditions ( $\left.2 \mathrm{~h}, \mathrm{pH} 2.5\right)$, but during simulated gastric digestion, Nile red (used as a hydrophobic substance model) was not released. The authors suggested potential for enteric delivery, even though such an approach was not tested.

Preparation of casein nanoparticles aided by application of cross-linking agents has been studied. Kumar and Singh prepared nanoparticles from casein and silk fibroin blend cross-linked with glutaraldehyde [89]. Particles were optimised using an in silico approach before preparation. Carvedilol in dimethylformamide was added to pre-fabricated nanoparticles, and after stirring and sonication the suspension was dialysed against water. The optimised formulation exhibited spherical shape and a twofold increase in maximum observed plasma concentration as well as 6.87 times increase in bioavailability compared with aqueous solution during in vivo experiments in rats. In another study, glutaraldehyde cross-linked casein was used to encapsulate magnetic particles [90]. Methanolic solution of doxorubicin was mixed with magnetic iron oxide nanoparticles coated with polymaleate and octadecene copolymer and incubated to allow the drug to be incorporated into the hydrophobic layer of the polymer. Particles were then coated with casein by deposition of casein molecules onto the particles followed by glutaraldehyde cross-linking. The casein-coated nanoparticles showed enhanced permeability compared with uncoated particles in ex vivo experiments. This phenomenon is thought to be attributable to energy-independent penetration of the plasma membrane by casein molecules $[39,90]$. Additionally, the casein outer layer was shown to be resistant to pepsin at low $\mathrm{pH}$ and was digested by trypsin at neutral $\mathrm{pH}$ [90]. Clearly, glutaraldehyde cross-linking is responsible for the inhibition of gastric digestion of the otherwise readily digestible casein. This knowledge can be used to control digestion of nanocapsules targeted for the intestine. Even though glutaraldehyde is toxic [91], there are long established methods for determination of the smallest amounts of glutaraldehyde [92, 93], allowing monitoring of the reaction with proteins [92].

Glutaraldehyde can be substituted with non-toxic, or less toxic, cross-linking agents. Zhen et al. used transglutaminase to cross-link casein for preparation of nanoparticles loaded with cisplatin [94]. Nanoparticles enabled deep penetration into tumour tissue, and in mice with hepatic tumour growth, inhibition was better than with free cisplatin.

Cross-linked casein nanoparticles were recently used for preparation of swellable floating tablets [95]. Alfuzosin hydrochloride was dissolved directly in casein solution, and genipin in ethanol was added to achieve cross-linking. Nanoparticles were obtained by spray-drying $[95,96]$. Powdered nanoparticles were then tableted using a single-punch tablet press. Tablets obtained by this method were compared with marketed alfuzosin formulation. Casein-based tablets floated much faster than marketed ones. Both formulations prolonged alfuzosin release for $24 \mathrm{~h}$ [95], whereas drug release could be modulated by altering the cross-linking degree in the case of the casein tablets $[95,96]$.

One of the most interesting papers describes nanoencapsulation in a freezeconcentrated (cryocentrated) phase [97]. This phase can be defined as a microspace with high concentration of ice crystals forming during freezing in aqueous solution. 
Casein and $\beta$-carotene were mixed and steadily frozen at $-40{ }^{\circ} \mathrm{C}$, then freeze-dried under vacuum at $-20{ }^{\circ} \mathrm{C}$. $\beta$-Carotene molecules were enclosed between the surface and interior of the nanoparticles. When aging under frozen conditions was introduced, the amount of $\beta$-carotene on the surface increased, along with the surface hydrophobicity. However, after rehydration, the surface hydrophobicity reverted.

\section{$2.3 \boldsymbol{\beta}$-Casein nanoparticles}

The ability to self-assemble is also observed for individual casein peptides such as $\beta$-casein, which forms globular micelles composed of 15-60 molecules with hydrodynamic radius of $7-14 \mathrm{~nm}[98,99]$. Extraction of $\beta$-casein involves three consecutive steps: separation of whole casein from milk, and isolation of $\beta$-casein; micelle disruption by acidification, chelation or cooling, and purification; washing, precipitation and separation [100].

$\beta$-Casein is found in micelles at $\mathrm{pH}$ above $\mathrm{pI}(5.33)$ and $15-30{ }^{\circ} \mathrm{C}$, but is monomeric at $0-8{ }^{\circ} \mathrm{C}[7,101]$, making these conformational changes temperaturedriven characteristics. At $24{ }^{\circ} \mathrm{C}$ and $\mathrm{pH} \mathrm{2.6}$, below pI, $\beta$-casein is present as round disk-like assemblies with width of 3-4 nm and diameter of 20-25 nm [102]. The $\mathrm{CMC}$ of $\beta$-casein is $0.3-0.7 \mathrm{mg} / \mathrm{ml}$ and depends on $\mathrm{pH}$, temperature and ionic strength [99]. $\beta$-Casein molecules have charged hydrophilic $\mathrm{N}$-terminal regions, whose electrostatic repulsion combined with the attraction of hydrophobic domains forms the basis of its micellisation (Fig. 2) [99]. The majority of the hydrophilic residues form the shell, while most of the hydrophobic residues form the core of $\beta$ casein micelles [103]. In fact, its behaviour resembles diblock copolymers [104].

In recent years, $\beta$-casein has been used for encapsulation of hydrophobic therapeuticals including celecoxib [105-107], ibuprofen [108], mitoxantrone [109, 110], naringenin [111], paclitaxel [112, 113], tariquidar [112] as well as Vinca alkaloids (vinblastine), taxanes (paclitaxel and docetaxel) and camptothecins (irinotecan) [101].

The $\beta$-casein used in the above works was of bovine origin, but casein produced by other species can also be used successfully. Interestingly, Esmaili et al. encapsulated curcumin in nanoparticles based on camel $\beta$-casein [114], although broader application may be limited as this encapsulation material is quite uncommon.

Similarly to whole casein, $\beta$-casein also offers protective abilities, in this case against lyophilisation [105].

\section{Conclusions}

This review presents the perspectives for utilisation of caseins as encapsulation material. Caseins, being dietary proteins, are considered to be GRAS and are expected to be biocompatible, biodegradable and bioresorbable on oral administration. Their easy access and relatively high concentration in the raw material from which they are obtained, i.e. milk, make caseins inexpensive. Production of caseins 
is well known, long established and considered simple. Their flexible and unfolded conformation provides them with resistance to denaturation, which is beneficial during processing and manufacture.

The behaviour of casein micelles is driven by changes of $\mathrm{pH}$, causing them to shrink in an acidic environment. This phenomenon is anticipated to confer protection of substances encapsulated in casein during passage through the harsh environment of the stomach. The open structure of caseins makes them vulnerable to proteolytic digestion, which in some cases can be beneficial, such as for complete release of encapsulated substances, but disadvantageous in others, e.g. unchecked burst release, but can be controlled by utilising cross-linking agents. This is probably due to rigidisation of protein structure and blocking of residues recognised by proteolytic enzymes. Caseins have also been shown to penetrate the plasma membrane in an energy-independent fashion, ensuring enhanced cellular uptake of encapsulated substances.

Casein has been used for both microencapsulation and nanoencapsulation of biologically active agents, including pharmaceuticals, probiotic cells, nutraceuticals and nutrients. Encapsulation approaches for pharmaceuticals differ from methods used for other substances, but this does not limit their potential for future work. Indeed, many approaches tested for nutraceuticals were eventually used for pharmaceuticals.

The remarkable gelation properties of casein have been used to prepare microcapsules that can encapsulate cells of probiotic bacteria. This process was facilitated by the enzymatic action of rennet or transglutaminase. However, additional work is necessary to improve the survival rate and stability of cells during storage. Much progress has also been made on coacervation of casein with polysaccharides to encapsulate hydrophobic substances. This process can be achieved by adjusting the $\mathrm{pH}$ to low values, as caseins gain positive charge in acidic $\mathrm{pH}$, and can thus interact with the negative charge on polysaccharides. However, such methods are probably limited to acid-insensitive substances, as others may be damaged.

Caseins are naturally designed to bind and encapsulate high concentrations of calcium phosphate, via self-assembly into micelles. This, combined with the block distribution of hydrophobic regions of caseins, enables them to interact with lipophilic substances, providing a basis for nanoencapsulation of hydrophobic substances. In brief, particular factors are utilised to disrupt the micellar structure, hydrophobic substances are added and bind to caseins, followed by removal of disrupting factors and subsequent reassembly of caseins into micelles with the substances of interest entrapped inside. Such nanoparticles can provide solubilisation of lipophilic compounds in water-based solutions, in addition to improved bioavailability and protection against certain conditions. Recently, self-assembly was also studied for isolated $\beta$-casein. This biopolymer has a diblock structure in terms of charge and hydrophobicity distribution along the chain, providing the foundation for its spontaneous micellisation. From 0 to $30{ }^{\circ} \mathrm{C}, \beta$-casein changes from monomeric to micellised. This temperature-driven process in such a mild thermal range suggests great potential for nanoencapsulation of sensitive compounds. 
Different casein nanoparticles have been shown to protect their contents against cold (storage and lyophilisation), heat, oxidation, UV radiation, high hydrostatic pressure processing and changes of $\mathrm{pH}$ and ionic strength.

Open Access This article is distributed under the terms of the Creative Commons Attribution 4.0 International License (http://creativecommons.org/licenses/by/4.0/), which permits unrestricted use, distribution, and reproduction in any medium, provided you give appropriate credit to the original author(s) and the source, provide a link to the Creative Commons license, and indicate if changes were made.

\section{References}

1. Beezer GR (1940) Latin and Greek roots in chemical terminology. J Chem Educ 17:63-66. doi:10. 1021/ed017p63

2. Holt C, Carver JA, Ecroyd H, Thorn DC (2013) Invited review: caseins and the casein micelle: their biological functions, structures, and behavior in foods. J Dairy Sci 96:6127-6146. doi:10.3168/jds. 2013-6831

3. Artym J, Zimecki M (2013) Milk-derived proteins and peptides in clinical trials. Postępy Hig Med Dośw Online 67:800-816

4. Pereira PC (2014) Milk nutritional composition and its role in human health. Nutrition 30:619-627. doi:10.1016/j.nut.2013.10.011

5. Elzoghby AO, Abo El-Fotoh WS, Elgindy NA (2011) Casein-based formulations as promising controlled release drug delivery systems. J Control Release 153:206-216. doi:10.1016/j.jconrel. 2011.02.010

6. Caroli AM, Chessa S, Erhardt GJ (2009) Invited review: milk protein polymorphisms in cattle: effect on animal breeding and human nutrition. J Dairy Sci 92:5335-5352. doi:10.3168/jds.20092461

7. Abd El-Salam MH, El-Shibiny S (2012) Formation and potential uses of milk proteins as nano delivery vehicles for nutraceuticals: a review. Int J Dairy Technol 65:13-21. doi:10.1111/j.14710307.2011.00737.x

8. Farrell HM Jr, Malin EL, Brown EM, Qi PX (2006) Casein micelle structure: what can be learned from milk synthesis and structural biology? Curr Opin Colloid Interface Sci 11:135-147. doi:10. 1016/j.cocis.2005.11.005

9. Livney YD (2010) Milk proteins as vehicles for bioactives. Curr Opin Colloid Interface Sci 15:73-83. doi:10.1016/j.cocis.2009.11.002

10. Audic J-L, Chaufer B, Daufin G (2003) Non-food applications of milk components and dairy coproducts: a review. Le Lait 83:417-438. doi:10.1051/lait:2003027

11. Fox PF, Brodkorb A (2008) The casein micelle: historical aspects, current concepts and significance. Int Dairy J 18:677-684. doi:10.1016/j.idairyj.2008.03.002

12. Swaisgood HE (2003) Chemistry of the caseins. In: Fox PF, McSweeney PLH (eds) Advanced dairy chemistry proteins. Springer, New Mexico, pp 139-201

13. Kessler A, Menéndez-Aguirre O, Hinrichs J et al (2014) $\alpha_{\mathrm{s}}$-Casein-PE6400 mixtures: surface properties, miscibility and self-assembly. Colloids Surf B Biointerfaces 118:49-56. doi:10.1016/j. colsurfb.2014.03.030

14. de Kruif CG, Huppertz T, Urban VS, Petukhov AV (2012) Casein micelles and their internal structure. Adv Colloid Interface Sci 171-172:36-52. doi:10.1016/j.cis.2012.01.002

15. Trejo R, Dokland T, Jurat-Fuentes J, Harte F (2011) Cryo-transmission electron tomography of native casein micelles from bovine milk. J Dairy Sci 94:5770-5775. doi:10.3168/jds.2011-4368

16. Bouchoux A, Gésan-Guiziou G, Pérez J, Cabane B (2010) How to squeeze a sponge: casein micelles under osmotic stress, a SAXS study. Biophys J 99:3754-3762. doi:10.1016/j.bpj.2010.10. 019

17. CSN1S1-Alpha-S1-casein precursor-Bos taurus (Bovine)—CSN1S1 gene and protein. http://www. uniprot.org/uniprot/P02662. Accessed 10 Feb 2017

18. CSN1S2-Alpha-S2-casein precursor-Bos taurus (Bovine)-CSN1S2 gene and protein. http://www. uniprot.org/uniprot/P02663. Accessed 10 Feb 2017 
19. CSN2-Beta-casein precursor-Bos taurus (Bovine)—CSN2 gene and protein. http://www.uniprot. org/uniprot/P02666. Accessed 10 Feb 2017

20. CSN3-Kappa-casein precursor-Bos taurus (Bovine)—CSN3 gene and protein. http://www.uniprot. org/uniprot/P02668. Accessed 10 Feb 2017

21. De Sa Peixoto P, Silva JVC, Laurent G et al (2017) How high concentrations of proteins stabilize the amorphous state of calcium orthophosphate: a solid-state nuclear magnetic resonance (NMR) study of the casein case. Langmuir 33:1256-1264. doi:10.1021/acs.langmuir.6b04235

22. Gonzalez-Jordan A, Thomar P, Nicolai T, Dittmer J (2015) The effect of pH on the structure and phosphate mobility of casein micelles in aqueous solution. Food Hydrocoll 51:88-94. doi:10.1016/j. foodhyd.2015.04.024

23. Tagliabracci VS, Engel JL, Wen J et al (2012) Secreted kinase phosphorylates extracellular proteins that regulate biomineralization. Science 336:1150-1153. doi:10.1126/science.1217817

24. Gebhardt R, Vendrely C, Kulozik U (2011) Structural characterization of casein micelles: shape changes during film formation. J Phys Condens Matter 23:444201. doi:10.1088/0953-8984/23/44/ 444201

25. Jollès P (1979) The carbohydrate portions of milk glycoproteins. J Dairy Res 46:187-191. doi:10. 1017/S0022029900017027

26. Dalgleish DG (1998) Casein micelles as colloids: surface structures and stabilities. J Dairy Sci 81:3013-3018. doi:10.3168/jds.S0022-0302(98)75865-5

27. de Kruif CG, Holt C (2003) Casein micelle structure, functions and interactions. In: Fox PF, McSweeney PLH (eds) Advanced dairy chemistry proteins. Springer, New Mexico, pp 233-276

28. Bauman DE, Mather IH, Wall RJ, Lock AL (2006) Major advances associated with the biosynthesis of milk. J Dairy Sci 89:1235-1243. doi:10.3168/jds.S0022-0302(06)72192-0

29. Liu Y, Guo R (2008) pH-dependent structures and properties of casein micelles. Biophys Chem 136:67-73. doi:10.1016/j.bpc.2008.03.012

30. Liu Z, Juliano P, Williams RP et al (2014) Ultrasound effects on the assembly of casein micelles in reconstituted skim milk. J Dairy Res 81:146-155. doi:10.1017/S0022029913000721

31. Tuinier R, de Kruif CG (2002) Stability of casein micelles in milk. J Chem Phys 117:1290-1295. doi:10.1063/1.1484379

32. Suárez-Luque S, Mato I, Huidobro JF, Simal-Lozano J (2007) Determination of major metal cations in milk by capillary zone electrophoresis. Int Dairy J 17:896-901. doi:10.1016/j.idairyj.2006.12.004

33. Ye R, Harte F (2013) Casein maps: effect of ethanol, $\mathrm{pH}$, temperature, and $\mathrm{CaCl}_{2}$ on the particle size of reconstituted casein micelles. J Dairy Sci 96:799-805. doi:10.3168/jds.2012-5838

34. Thomar P, Nicolai T, Benyahia L, Durand D (2013) Comparative study of the rheology and the structure of sodium and calcium caseinate solutions. Int Dairy J 31:100-106. doi:10.1016/j.idairyj. 2013.02.005

35. Thomar P, Benyahia L, Durand D, Nicolai T (2014) The influence of adding monovalent salt on the rheology of concentrated sodium caseinate suspensions and the solubility of calcium caseinate. Int Dairy J 37:48-54. doi:10.1016/j.idairyj.2014.02.007

36. Philippe M, Le Graët Y, Gaucheron F (2005) The effects of different cations on the physicochemical characteristics of casein micelles. Food Chem 90:673-683. doi:10.1016/j.foodchem.2004. 06.001

37. Salque M, Bogucki PI, Pyzel J et al (2013) Earliest evidence for cheese making in the sixth millennium bc in northern Europe. Nature 493:522-525. doi:10.1038/nature11698

38. Quigley EMM, Turnberg LA (1987) $\mathrm{pH}$ of the microclimate lining human gastric and duodenal mucosa in vivo. Gastroenterology 92:1876-1884

39. Liu C, Yao W, Zhang L et al (2010) Cell-penetrating hollow spheres based on milk protein. Chem Commun 46:7566-7568. doi:10.1039/C0CC02370A

40. Semo E, Kesselman E, Danino D, Livney YD (2007) Casein micelle as a natural nano-capsular vehicle for nutraceuticals. Food Hydrocoll 21:936-942. doi:10.1016/j.foodhyd.2006.09.006

41. Peixoto PDS, Bouchoux A, Huet S et al (2015) Diffusion and partitioning of macromolecules in casein microgels: evidence for size-dependent attractive interactions in a dense protein system. Langmuir 31:1755-1765. doi:10.1021/la503657u

42. Vert M, Doi Y, Hellwich K-H et al (2012) Terminology for biorelated polymers and applications (IUPAC recommendations 2012). Pure Appl Chem 84:377-410. doi:10.1351/PAC-REC-10-12-04

43. Chen Y, Willmott N, Anderson J, Florence AT (1987) Comparison of albumin and casein microspheres as a carrier for doxorubicin. J Pharm Pharmacol 39:978-985. doi:10.1111/j.2042-7158. 1987.tb03144.x 
44. Desoize B, Jardillier JC, Kanoun K et al (1986) In-vitro cytotoxic activity of cross-linked protein microcapsules. J Pharm Pharmacol 38:8-13. doi:10.1111/j.2042-7158.1986.tb04458.x

45. Burgain J, Gaiani C, Cailliez-Grimal C et al (2013) Encapsulation of Lactobacillus rhamnosus GG in microparticles: influence of casein to whey protein ratio on bacterial survival during digestion. Innov Food Sci Emerg Technol 19:233-242. doi:10.1016/j.ifset.2013.04.012

46. Heidebach T, Först P, Kulozik U (2009) Transglutaminase-induced caseinate gelation for the microencapsulation of probiotic cells. Int Dairy J 19:77-84. doi:10.1016/j.idairyj.2008.08.003

47. Heidebach T, Först P, Kulozik U (2010) Influence of casein-based microencapsulation on freezedrying and storage of probiotic cells. J Food Eng 98:309-316. doi:10.1016/j.jfoodeng.2010.01.003

48. Würth R, Hörmannsperger G, Wilke J et al (2015) Protective effect of milk protein based microencapsulation on bacterial survival in simulated gastric juice versus the murine gastrointestinal system. J Funct Foods 15:116-125. doi:10.1016/j.jff.2015.02.046

49. Wine Y, Cohen-Hadar N, Freeman A, Frolow F (2007) Elucidation of the mechanism and end products of glutaraldehyde crosslinking reaction by X-ray structure analysis. Biotechnol Bioeng 98:711-718. doi:10.1002/bit.21459

50. Griffin M, Casadio R, Bergamini CM (2002) Transglutaminases: nature's biological glues. Biochem J 368:377-396. doi:10.1042/bj20021234

51. Butler MF, Ng Y-F, Pudney PDA (2003) Mechanism and kinetics of the crosslinking reaction between biopolymers containing primary amine groups and genipin. J Polym Sci Part Polym Chem 41:3941-3953. doi:10.1002/pola.10960

52. Guerin J, Petit J, Burgain J et al (2017) Lactobacillus rhamnosus GG encapsulation by spray-drying: milk proteins clotting control to produce innovative matrices. J Food Eng 193:10-19. doi:10.1016/j. jfoodeng.2016.08.008

53. Jain A, Thakur D, Ghoshal G et al (2016) Characterization of microcapsulated $\beta$-carotene formed by complex coacervation using casein and gum tragacanth. Int J Biol Macromol 87:101-113. doi:10.1016/j.ijbiomac.2016.01.117

54. Jain A, Thakur D, Ghoshal G et al (2016) Formation and functional attributes of electrostatic complexes involving casein and anionic polysaccharides: an approach to enhance oral absorption of lycopene in rats in vivo. Int J Biol Macromol 93:746-756. doi:10.1016/j.ijbiomac.2016.08.071

55. Koupantsis T, Pavlidou E, Paraskevopoulou A (2014) Flavour encapsulation in milk proteins-CMC coacervate-type complexes. Food Hydrocoll 37:134-142. doi:10.1016/j.foodhyd.2013.10.031

56. Koupantsis T, Pavlidou E, Paraskevopoulou A (2016) Glycerol and tannic acid as applied in the preparation of milk proteins-CMC complex coavervates for flavour encapsulation. Food Hydrocoll 57:62-71. doi:10.1016/j.foodhyd.2016.01.007

57. Marreto RN, Ramos MFS, Silva EJ et al (2013) Impact of cross-linking and drying method on drug delivery performance of casein-pectin microparticles. AAPS PharmSciTech 14:1227-1235. doi:10. 1208/s12249-013-0012-8

58. Matalanis A, Decker EA, McClements DJ (2012) Inhibition of lipid oxidation by encapsulation of emulsion droplets within hydrogel microspheres. Food Chem 132:766-772. doi:10.1016/j. foodchem.2011.11.034

59. Chen F, Liang L, Zhang Z et al (2017) Inhibition of lipid oxidation in nanoemulsions and filled microgels fortified with omega-3 fatty acids using casein as a natural antioxidant. Food Hydrocoll 63:240-248. doi:10.1016/j.foodhyd.2016.09.001

60. Goyal A, Sharma V, Sihag MK et al (2015) Development and physico-chemical characterization of microencapsulated flaxseed oil powder: a functional ingredient for omega-3 fortification. Powder Technol 286:527-537. doi:10.1016/j.powtec.2015.08.050

61. Mounsey JS, O’Kennedy BT, Kelly PM (2005) Comparison of re-micellised casein prepared from acid casein with micellar casein prepared by membrane filtration. Le Lait 85:419-430. doi:10.1051/ lait:2005022

62. Chu B-S, Ichikawa S, Kanafusa S, Nakajima M (2007) Preparation and characterization of $\beta$ carotene nanodispersions prepared by solvent displacement technique. J Agric Food Chem 55:6754-6760. doi:10.1021/jf063609d

63. Chu B-S, Ichikawa S, Kanafusa S, Nakajima M (2007) Preparation of protein-stabilized $\beta$-carotene nanodispersions by emulsification-evaporation method. J Am Oil Chem Soc 84:1053-1062. doi:10. 1007/s11746-007-1132-7

64. Ghasemi S, Abbasi S (2014) Formation of natural casein micelle nanocapsule by means of $\mathrm{pH}$ changes and ultrasound. Food Hydrocoll 42(Part 1):42-47. doi:10.1016/j.foodhyd.2013.10.028 
65. Roach A, Dunlap J, Harte F (2009) Association of triclosan to casein proteins through solventmediated high-pressure homogenization. J Food Sci 74:N23-N29. doi:10.1111/j.1750-3841.2009. 01048.x

66. Huppertz T, Grosman S, Fox PF, Kelly AL (2004) Heat and ethanol stabilities of high-pressuretreated bovine milk. Int Dairy J 14:125-133. doi:10.1016/S0958-6946(03)00170-5

67. Elzoghby AO, Helmy MW, Samy WM, Elgindy NA (2013) Micellar delivery of flutamide via milk protein nanovehicles enhances its anti-tumor efficacy in androgen-dependent prostate cancer rat model. Pharm Res 30:2654-2663. doi:10.1007/s11095-013-1091-7

68. Elzoghby AO, Helmy MW, Samy WM, Elgindy NA (2013) Spray-dried casein-based micelles as a vehicle for solubilization and controlled delivery of flutamide: formulation, characterization, and in vivo pharmacokinetics. Eur J Pharm Biopharm 84:487-496. doi:10.1016/j.ejpb.2013.01.005

69. Pan K, Zhong Q, Baek SJ (2013) Enhanced dispersibility and bioactivity of curcumin by encapsulation in casein nanocapsules. J Agric Food Chem 61:6036-6043. doi:10.1021/jf400752a

70. Pan K, Luo Y, Gan Y et al (2014) pH-driven encapsulation of curcumin in self-assembled casein nanoparticles for enhanced dispersibility and bioactivity. Soft Matter 10:6820-6830. doi:10.1039/ C4SM00239C

71. Yazdi SR, Bonomi F, Iametti S et al (2013) Binding of curcumin to milk proteins increases after static high pressure treatment of skim milk. J Dairy Res 80:152-158. doi:10.1017/ S0022029913000125

72. Menéndez-Aguirre O, Stuetz W, Grune T et al (2011) High pressure-assisted encapsulation of vitamin $\mathrm{D}_{2}$ in reassembled casein micelles. High Press Res 31:265-274. doi:10.1080/08957959. 2011.565057

73. Menéndez-Aguirre O, Kessler A, Stuetz W et al (2014) Increased loading of vitamin $D_{2}$ in reassembled casein micelles with temperature-modulated high pressure treatment. Food Res Int 64:74-80. doi:10.1016/j.foodres.2014.06.010

74. Haham M, Ish-Shalom S, Nodelman M et al (2012) Stability and bioavailability of vitamin D nanoencapsulated in casein micelles. Food Funct 3:737. doi:10.1039/c2fo10249h

75. Levinson Y, Ish-Shalom S, Segal E, Livney YD (2016) Bioavailability, rheology and sensory evaluation of fat-free yogurt enriched with $\mathrm{VD}_{3}$ encapsulated in re-assembled casein micelles. Food Funct 7:1477-1482. doi:10.1039/C5FO01111F

76. Cohen Y, Ish-Shalom S, Segal E et al (2017) The bioavailability of vitamin $\mathrm{D}_{3}$, a model hydrophobic nutraceutical, in casein micelles, as model protein nanoparticles: human clinical trial results. J Funct Foods 30:321-325. doi:10.1016/j.jff.2017.01.019

77. Sáiz-Abajo M-J, González-Ferrero C, Moreno-Ruiz A et al (2013) Thermal protection of $\beta$-carotene in re-assembled casein micelles during different processing technologies applied in food industry. Food Chem 138:1581-1587. doi:10.1016/j.foodchem.2012.11.016

78. Jarunglumlert T, Nakagawa K, Adachi S (2015) Influence of aggregate structure of casein on the encapsulation efficiency of $\beta$-carotene entrapped via hydrophobic interaction. Food Struct 5:42-50. doi:10.1016/j.foostr.2015.05.001

79. Yi J, Lam TI, Yokoyama W et al (2015) Beta-carotene encapsulated in food protein nanoparticles reduces peroxyl radical oxidation in Caco-2 cells. Food Hydrocoll 43:31-40. doi:10.1016/j.foodhyd. 2014.04.028

80. Zhang Y, He S, Ma Y et al (2015) Characterization and bioaccessibility of $\beta$-carotene in reassembled casein. RSC Adv 5:77595-77600. doi:10.1039/C5RA07736B

81. Penalva R, Esparza I, Agüeros M et al (2015) Casein nanoparticles as carriers for the oral delivery of folic acid. Food Hydrocoll 44:399-406. doi:10.1016/j.foodhyd.2014.10.004

82. Zimet P, Rosenberg D, Livney YD (2011) Re-assembled casein micelles and casein nanoparticles as nano-vehicles for $\omega-3$ polyunsaturated fatty acids. Food Hydrocoll 25:1270-1276. doi:10.1016/j. foodhyd.2010.11.025

83. Koo SY, Mok I-K, Pan C-H, Kim SM (2016) Preparation of fucoxanthin-loaded nanoparticles composed of casein and chitosan with improved fucoxanthin bioavailability. J Agric Food Chem 64:9428-9435. doi:10.1021/acs.jafc.6b04376

84. Luo Y, Pan K, Zhong Q (2015) Casein/pectin nanocomplexes as potential oral delivery vehicles. Int J Pharm 486:59-68. doi:10.1016/j.ijpharm.2015.03.043

85. Chen H, Zhang Y, Zhong Q (2015) Physical and antimicrobial properties of spray-dried zein-casein nanocapsules with co-encapsulated eugenol and thymol. J Food Eng 144:93-102. doi:10.1016/j. jfoodeng.2014.07.021 
86. Pan X, Yao P, Jiang M (2007) Simultaneous nanoparticle formation and encapsulation driven by hydrophobic interaction of casein-graft-dextran and $\beta$-carotene. J Colloid Interface Sci 315:456-463. doi:10.1016/j.jcis.2007.07.015

87. Pan X, Mu M, Hu B et al (2006) Micellization of casein-graft-dextran copolymer prepared through Maillard reaction. Biopolymers 81:29-38. doi:10.1002/bip.20372

88. Markman G, Livney YD (2012) Maillard-conjugate based core-shell co-assemblies for nanoencapsulation of hydrophobic nutraceuticals in clear beverages. Food Funct 3:262-270. doi:10.1039/ C1FO10220F

89. Kumar S, Singh SK (2017) In silico-in vitro-in vivo studies of experimentally designed carvedilol loaded silk fibroin-casein nanoparticles using physiological based pharmacokinetic model. Int J Biol Macromol 96:403-420. doi:10.1016/j.ijbiomac.2016.12.052

90. Huang J, Shu Q, Wang L et al (2015) Layer-by-layer assembled milk protein coated magnetic nanoparticle enabled oral drug delivery with high stability in stomach and enzyme-responsive release in small intestine. Biomaterials 39:105-113. doi:10.1016/j.biomaterials.2014.10.059

91. Zeiger E, Gollapudi B, Spencer P (2005) Genetic toxicity and carcinogenicity studies of glutaraldehyde—a review. Mutat Res Mutat Res 589:136-151. doi:10.1016/j.mrrev.2005.01.001

92. Boratyński J, Żal T (1990) Colorimetric micromethods for glutaraldehyde determination by means of phenol and sulfuric acid or phenol and perchloric acid. Anal Biochem 184:259-262. doi:10.1016/ 0003-2697(90)90677-2

93. Sawicki E, Hauser TR, Stanley TW, Elbert W (1961) The 3-methyl-2-benzothiazolone hydrazone test. Sensitive new methods for the detection, rapid estimation, and determination of aliphatic aldehydes. Anal Chem 33:93-96. doi:10.1021/ac60169a028

94. Zhen X, Wang X, Xie C et al (2013) Cellular uptake, antitumor response and tumor penetration of cisplatin-loaded milk protein nanoparticles. Biomaterials 34:1372-1382. doi:10.1016/j.biomaterials. 2012.10.061

95. Elzoghby AO, Vranic BZ, Samy WM, Elgindy NA (2015) Swellable floating tablet based on spraydried casein nanoparticles: near-infrared spectral characterization and floating matrix evaluation. Int J Pharm 491:113-122. doi:10.1016/j.ijpharm.2015.06.015

96. Elzoghby AO, Samy WM, Elgindy NA (2013) Novel spray-dried genipin-crosslinked casein nanoparticles for prolonged release of alfuzosin hydrochloride. Pharm Res 30:512-522. doi:10. 1007/s11095-012-0897-z

97. Nakagawa K, Jarunglumlert T, Adachi S (2016) Structural changes in casein aggregates under frozen conditions affect the entrapment of hydrophobic materials and the digestibility of aggregates. Chem Eng Sci 143:287-296. doi:10.1016/j.ces.2016.01.001

98. Portnaya I, Cogan U, Livney YD et al (2006) Micellization of bovine $\beta$-casein studied by isothermal titration microcalorimetry and cryogenic transmission electron microscopy. J Agric Food Chem 54:5555-5561. doi:10.1021/jf060119c

99. Faizullin DA, Konnova TA, Haertlé T, Zuev YF (2017) Secondary structure and colloidal stability of beta-casein in microheterogeneous water-ethanol solutions. Food Hydrocoll 63:349-355. doi:10. 1016/j.foodhyd.2016.09.011

100. Atamer Z, Post AE, Schubert T et al (2017) Bovine $\beta$-casein: isolation, properties and functionality. A review. Int Dairy J 66:115-125. doi:10.1016/j.idairyj.2016.11.010

101. Shapira A, Assaraf YG, Epstein D, Livney YD (2010) Beta-casein nanoparticles as an oral delivery system for chemotherapeutic drugs: impact of drug structure and properties on co-assembly. Pharm Res 27:2175-2186. doi:10.1007/s11095-010-0222-7

102. Portnaya I, Ben-Shoshan E, Cogan U et al (2008) Self-assembly of bovine $\beta$-casein below the isoelectric pH. J Agric Food Chem 56:2192-2198. doi:10.1021/jf072630r

103. de Kruif CG, Grinberg VY (2002) Micellisation of $\beta$-casein. Colloids Surf Physicochem Eng Asp 210:183-190. doi:10.1016/S0927-7757(02)00371-0

104. Horne DS (2002) Casein structure, self-assembly and gelation. Curr Opin Colloid Interface Sci 7:456-461. doi:10.1016/S1359-0294(02)00082-1

105. Bachar M, Mandelbaum A, Portnaya I et al (2012) Development and characterization of a novel drug nanocarrier for oral delivery, based on self-assembled $\beta$-casein micelles. J Control Release 160:164-171. doi:10.1016/j.jconrel.2012.01.004

106. Perlstein H, Turovsky T, Gimeson P et al (2015) Thermotropic behavior of celecoxib-loaded betacasein micelles: relevance to the improved bioavailability. Eur J Nanomed 7:303-312. doi:10.1515/ ejnm-2015-0023 
107. Turovsky T, Khalfin R, Kababya S et al (2015) Celecoxib encapsulation in $\beta$-casein micelles: structure, interactions, and conformation. Langmuir 31:7183-7192. doi:10.1021/acs.langmuir. 5 b01397

108. Turovsky T, Portnaya I, Kesselman E et al (2015) Effect of temperature and loading on the structure of $\beta$-casein/ibuprofen assemblies. J Colloid Interface Sci 449:514-521. doi:10.1016/j.jcis.2015.02. 030

109. Shapira A, Assaraf YG, Livney YD (2010) Beta-casein nanovehicles for oral delivery of chemotherapeutic drugs. Nanomed Nanotechnol Biol Med 6:119-126. doi:10.1016/j.nano.2009.06. 006

110. Shapira A, Markman G, Assaraf YG, Livney YD (2010) $\beta$-Casein-based nanovehicles for oral delivery of chemotherapeutic drugs: drug-protein interactions and mitoxantrone loading capacity. Nanomed Nanotechnol Biol Med 6:547-555. doi:10.1016/j.nano.2010.01.003

111. Moeiniafshari A-A, Zarrabi A, Bordbar A-K (2015) Exploring the interaction of naringenin with bovine beta-casein nanoparticles using spectroscopy. Food Hydrocoll 51:1-6. doi:10.1016/j. foodhyd.2015.04.036

112. Bar-Zeev M, Assaraf YG, Livney YD et al (2016) $\beta$-Casein nanovehicles for oral delivery of chemotherapeutic drug combinations overcoming P-glycoprotein-mediated multidrug resistance in human gastric cancer cells. Oncotarget 7:23322-23334. doi:10.18632/oncotarget.8019

113. Shapira A, Davidson I, Avni N et al (2012) $\beta$-Casein nanoparticle-based oral drug delivery system for potential treatment of gastric carcinoma: stability, target-activated release and cytotoxicity. Eur J Pharm Biopharm 80:298-305. doi:10.1016/j.ejpb.2011.10.022

114. Esmaili M, Ghaffari SM, Moosavi-Movahedi Z et al (2011) Beta casein-micelle as a nano vehicle for solubility enhancement of curcumin; food industry application. LWT-Food Sci Technol 44:2166-2172. doi:10.1016/j.1wt.2011.05.023 